\title{
OPEN Equatorial pliosaurid from Venezuela marks the youngest South American occurrence of the clade
}

\author{
Dylan Bastiaans $\mathbb{1}^{1}$, Daniel Madzia $\mathbb{1}^{2 \bowtie}$, Jorge D. Carrillo-Briceño $\mathbb{1}^{1}$ \& Sven Sachs ${ }^{3}$
}

Pliosaurids were the dominant macropredators in aquatic environments at least since the Middle Jurassic until their extinction in the early Late Cretaceous. Until very recently, the Cretaceous record of Pliosauridae has been poor and difficult to interpret from the taxonomic and phylogenetic perspective. Despite that the knowledge of Cretaceous pliosaurids improved in recent years, numerous aspects of their evolutionary history still remain only poorly known. Here, we report the first pliosaurid material from Venezuela. The taxon is most likely earliest Cenomanian in age, thus representing the youngest occurrence of Pliosauridae from South America. The Venezuelan taxon is based on a well-preserved tooth crown whose morphology and outer enamel structural elements appear to resemble especially those observable in the giant pliosaurid Sachicasaurus vitae from the Lower Cretaceous of Colombia. The new discovery extends the pliosaurid record on the continent by more than 10 million years and likely marks the southernmost Upper Cretaceous occurrence of Pliosauridae, worldwide. We also briefly discuss the affinities of the enigmatic Venezuelan elasmosaurid Alzadasaurus tropicus and highlight similarities to elasmosaurids from the Western Interior Seaway.

With the appearance of the Thalassophonea, possibly around the Early-Middle Jurassic transitional interval ${ }^{1}$, pliosaurids became the dominant macropredators in the aquatic environments. They played an important role as apex predators in marine ecosystems until their extinction possibly around the middle Turonian (early Late Cretaceous) (e.g., ${ }^{1-6}$ ). While Jurassic thalassophoneans have been intensively studied, especially those from the fossil-rich provenances in Europe (e.g., ${ }^{2,7-11}$ ), the Cretaceous representatives have long been neglected; and were based on patchy occurrences (e.g., ${ }^{12-22}$ ) with largely unexplored phylogenetic affinities (see, e.g., ${ }^{23}$ ). Recent studies, including establishments of new taxa from the Lower Cretaceous of Colombia ${ }^{24-26}$ and Russia ${ }^{27,28}$ and from the Upper Cretaceous of the United States ${ }^{3}$, reports of newly discovered, isolated pliosaurid material ${ }^{5,29-33}$ as well as reassessment of historical material ${ }^{4,31,34}$, led to a better understanding of pliosaurid phylogeny (e.g., ${ }^{1,2,6,26-28,35,36}$ ) and enabled some initial inferences of the divergence times and rates of their Cretaceous lineages ${ }^{1}$.

Despite that the knowledge of the Cretaceous thalassophonean pliosaurids has improved in recent years, still considerable efforts are necessary to obtain an accurate perception of the clade's diversity, disparity, and dispersal patterns during the final tens of millions of years of their evolutionary history.

Here, we report the first pliosaurid material from Venezuela. The new specimen originates from the midCretaceous succession of the La Luna Formation, Candelaria Municipality, Trujillo state, western Venezuela (Fig. 1) $)^{37-40}$. This find is significant because it represents the youngest record of Pliosauridae from the South American continent; younger by more than 10 million years than the late Aptian (late Early Cretaceous) 'Kronosaurus' boyacensis, the second youngest South American record ${ }^{15}$. It is also very likely the southernmost Upper Cretaceous occurrence of the clade, worldwide. The pliosaurid specimen also marks only the second plesiosaur record known from Venezuela. A partial elasmosaurid skeleton from the eastern part of the country (the affinities of which are discussed below) has been described in 1949 by Colbert ${ }^{41}$ and named Alzadasaurus tropicus.

The Venezuelan pliosaurid material described herein is a valuable addition to the scarce plesiosaur record of the mid-Cretaceous-i.e., Aptian-Albian to Cenomanian-Turonian ${ }^{42}$-of South America (Fig. 2). Plesiosaurs, in general, are extraordinarily rare in the mid-Cretaceous of South America. They are often represented by

\footnotetext{
${ }^{1}$ Palaeontological Institute and Museum, University of Zürich, Karl-Schmid-Strasse 4, 8006 Zürich, Switzerland. ${ }^{2}$ Institute of Paleobiology, Polish Academy of Sciences, Twarda 51/55, 00-818 Warszawa, Poland. ${ }^{3}$ Abteilung Geowissenschaften, Naturkunde-Museum Bielefeld, Adenauerplatz 2, 33602 Bielefeld, Germany. ${ }^{\circledR}$ email: daniel.madzia@gmail.com
} 

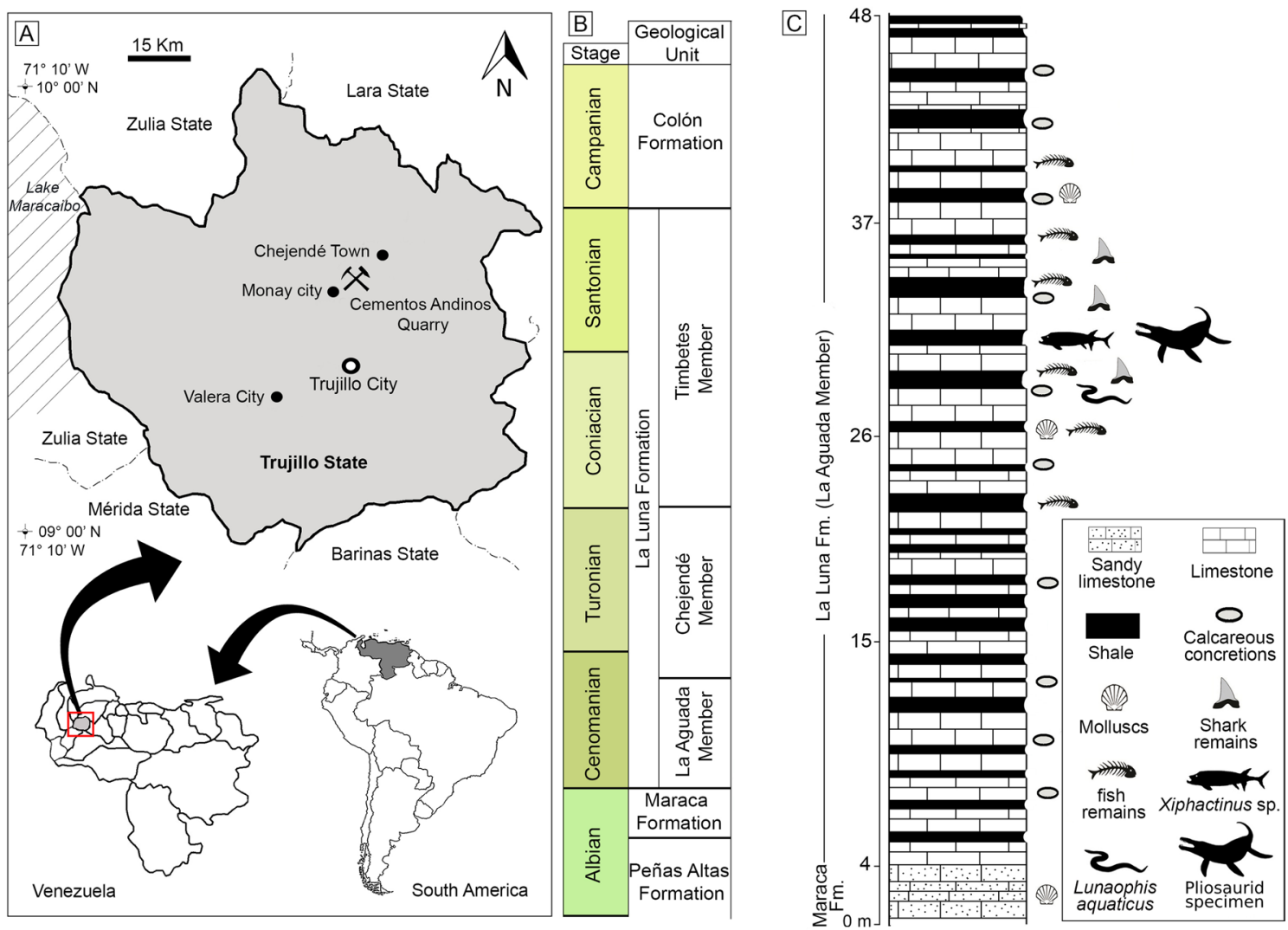

Figure 1. Location and geology of the "Cementos Andinos" quarry, Trujillo state, western Venezuela. (A) Location map. (B) Cretaceous lithostratigraphic units of the Chejendé region, near Monay city, Trujillo State (modified after ${ }^{38,39}$ ). (C) Stratigraphic section of the uppermost Maraca Formation and the La Aguada Member (La Luna Formation) in the "Cementos Andinos" quarry (modified by Jorge D. Carrillo-Briceño after ${ }^{37,40}$ and using Adobe Illustrator \& Photoshop [v2021.25.0]).

isolated fragmentary material, with the notable exception of the taxa originating from the upper Aptian (Lower Cretaceous) of the Paja Formation in Colombia ${ }^{15,36,43}$, and are not diagnostic beyond larger clades (Table 1). Despite that the new material is represented by an isolated tooth crown, its excellent preservation allows for a detailed description of its morphology and the outer enamel structural elements. Through comparisons with other Cretaceous pliosaurids, and by using multivariate analyses of pliosaurid dental features that have recently become available ${ }^{5}$, it is possible to determine its taxonomic affinities and an approximate phylogenetic placement.

Institutional abbreviations. AMNH, American Museum of Natural History, New York, USA; CAMSM, Sedgwick Museum of Earth Sciences, University of Cambridge, Cambridge, UK; DMNS, Denver Museum of Nature and Science, Denver, USA; FMNH, Field Museum of Natural History, Chicago, USA; GFMSU, Geological Faculty of Lomonosov Moscow State University, Museum at the academic base named after Prof. A. A. Bogdanov, Bakhchisaray district, Crimea; MCNC, Museo de Ciencias Naturales de Caracas, Caracas, Venezuela; MWGUW, Stanislaw Józef Thugutt Geological Museum, Warsaw, Poland; UNSM, University of Nebraska State Museum of Natural History, Lincoln, USA.

Geological and stratigraphic setting. The specimen MCNC-1830 originates from the La Aguada Member of the La Luna Formation at the "Cementos Andinos" quarry, where calcareous rocks are mined for cement production. The quarry is located in the Andes range (Cordillera de Mérida), east of Lake Maracaibo, $10 \mathrm{~km}$ to the northeast of Monay city, Candelaria Municipality, Trujillo state, western Venezuela (Fig. 1A). MCNC-1830 was collected in situ in 2014 by one of the authors (JDCB), at the top of the quarry $\left(9^{\circ} 36^{\prime} 52^{\prime \prime} \mathrm{N}, 70^{\circ} 24^{\prime} 3^{\prime \prime} \mathrm{W}\right.$ ), in the same outcrop of the La Aguada Member shown by ${ }^{37}$ (Fig. 3A in $^{37}$ ) (Fig. 1).

The La Luna Formation is the most prolific petroleum source rock in western Venezuela and part of eastern Colombia ${ }^{54-57}$, and represents a marine sequence deposited under anoxic-dysoxic conditions along the passive margin of northern South America during the Cenomanian-Campanian ${ }^{57}$. The La Luna Formation is an extensive geological unit that spans the foreland of the southern Caribbean Ridge, including a large part of northwest of Venezuela (Sierra de Perijá to the Mérida Andes) and to Colombia, and gradually transitions east into the contemporaneous Rio Querecual Formation (eastern Venezuela) which is equivalent in facies ${ }^{55}$. These concretions range from a few centimeters to well over a meter in length (e.g., ${ }^{37}$, Fig. 3C,D). In the southeast of the Maracaibo basin in the Lara and Trujillo states, the La Luna Formation is divided into three members (Fig. 1B): 


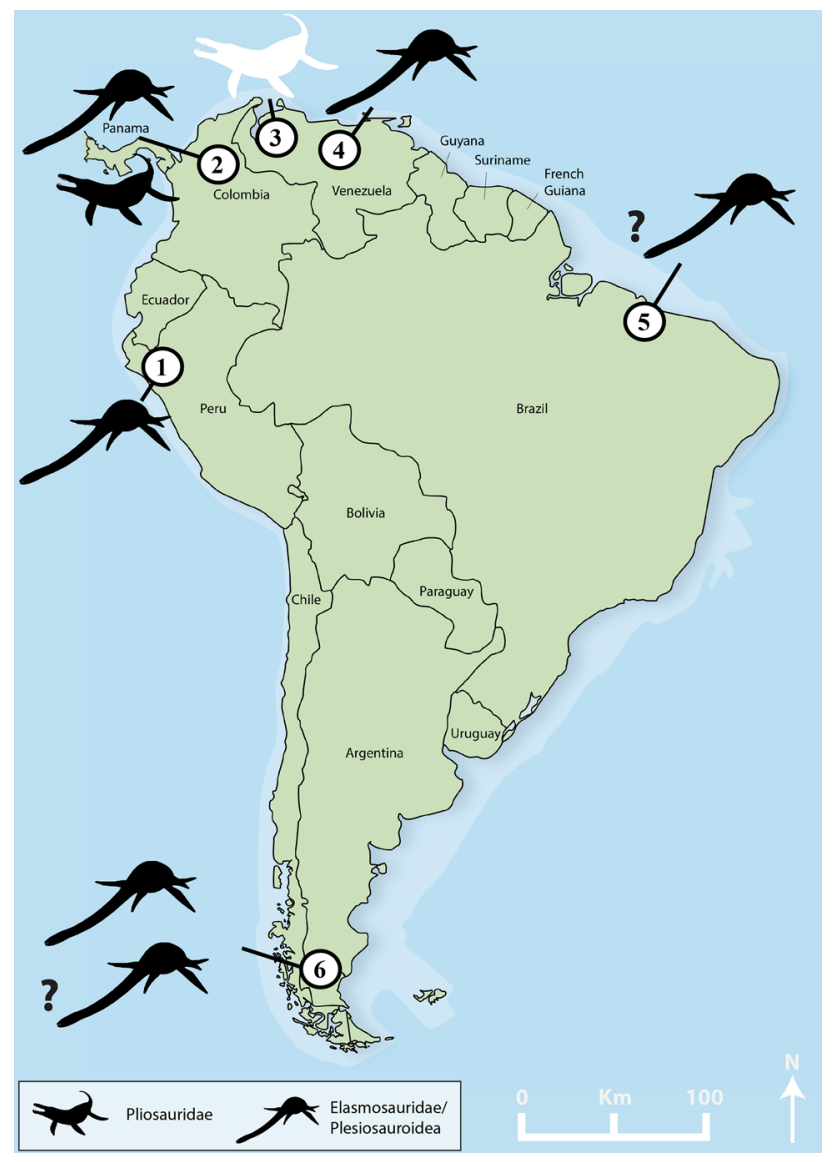

Figure 2. Distribution of mid-Cretaceous (Aptian-Turonian) plesiosaurs in South America. The new pliosaurid from the La Luna Formation is highlighted. (1) Jaén area, Romirón Fm., Peru; (2) Villa de Leiva, Paja Fm., Colombia; (3) Cementos Andinos Quarry, La Luna Fm., Venezuela; (4) Altagracia de Orituco area, Querecual Limestone, Venezuela; (5) Near Sao Luis, Alcântara Fm., Brazil; (6) Santa Cruz Province, Mata Amarilla Fm., Argentina. See Table 1 for details and references (map provided with permission by PD Dr. Torsten M. Scheyer; modified by Dylan Bastiaans using Adobe Illustrator \& Photoshop [v2021.25.0]).

\begin{tabular}{|c|c|c|c|c|c|c|c|}
\hline $\begin{array}{l}\text { Original taxonomic } \\
\text { assignment }\end{array}$ & Locality & Country & Unit & Stage $^{a}$ & Material & $\begin{array}{l}\text { Current taxonomic } \\
\text { assignment }\end{array}$ & $\mathbf{L I C}^{\mathbf{b}}$ \\
\hline $\begin{array}{l}\text { Alzadasaurus colombi- } \\
\text { ensis }^{14}\end{array}$ & Villa de Leiva & Colombia & Paja Formation & $\mathrm{uA}$ & $\begin{array}{l}\text { Several skeletons and } \\
\text { skeletal remains }\end{array}$ & $\begin{array}{l}\text { Callawayasaurus colombi- } \\
\text { ensis }^{36,43-47}\end{array}$ & Elasmosauridae \\
\hline Leivanectes bernardoi ${ }^{36,43}$ & Villa de Leiva & Colombia & Paja Formation & $\mathrm{uA}$ & Anterior half of the skull & As original & Elasmosauridae \\
\hline Kronosaurus boyacensis $^{15}$ & Villa de Leiva & Colombia & Paja Formation & $\mathrm{uA}$ & Largely complete skeleton & 'Kronosaurus' boyacensis ${ }^{26}$ & Brachaucheninae \\
\hline $\begin{array}{l}\text { Pliosauroidea?/Pliosauri- } \\
\text { dae? indet. }^{48}\end{array}$ & Jaén area & Peru & Romirón Formation & $\mathrm{uC}-\mathrm{lT}$ & Two vertebrae & Plesiosauria indet. & Plesiosauria \\
\hline Elasmosauridae indet. ${ }^{49}$ & Jaén area & Peru & Romirón Formation & $\mathrm{uC}-\mathrm{lT}$ & 5 cervical vertebrae & As original & Elasmosauridae \\
\hline Plesiosauria indet. ${ }^{50}$ & Near Sao Luís & Brazil & Alcântara Formation & $\mathrm{C}$ & Teeth & As original $^{51}$ & Plesiosauria \\
\hline Alzadasaurus tropicus ${ }^{41}$ & $\begin{array}{l}\text { Near Altagracia de } \\
\text { Orituco }\end{array}$ & Venezuela & Querecual limestone & $\mathrm{C}-\mathrm{T}$ & $\begin{array}{l}\text { Partial postcranial } \\
\text { skeleton }\end{array}$ & Elasmosauridae indet. ${ }^{44, \mathrm{c}}$ & Elasmosauridae \\
\hline Elasmosauridae indet. ${ }^{52}$ & Near Tres Lagos & Argentina & Mata Amarilla Formation & $\mathrm{C}-\mathrm{S}$ & $\begin{array}{l}\text { Teeth, vertebrae, pro- } \\
\text { podial }\end{array}$ & As original & Elasmosauridae \\
\hline $\begin{array}{l}\text { Polyptychodon patago- } \\
\text { nicus }^{53}\end{array}$ & Santa Cruz Province & Argentina & $\begin{array}{l}\text { ?Mata Amarilla Forma- } \\
\text { tion }\end{array}$ & $? \mathrm{C}-\mathrm{S}$ & Teeth & Plesiosauria indet. ${ }^{52}$ & Plesiosauria \\
\hline
\end{tabular}

Table 1. Locality information and literature references on the mid-Cretaceous plesiosaurs of South America. Welles $^{14,44}$, Hampe ${ }^{15}$, Páramo-Fonseca et al. ${ }^{26,36,43}$, Colbert ${ }^{41}$, Carpenter ${ }^{45}$, Jaillard et al. ${ }^{49}$, Carvalho et al..$^{50}$, O'Gorman and Varela ${ }^{52}$, Ameghino ${ }^{53}$, Jaimes and Parra ${ }^{46}$, Goñi and Gasparini ${ }^{47}$, Bôas and Carvalho ${ }^{51}$, MezaVelez and O'Gorman ${ }^{48}$. Note that Pliosauroidea?/Pliosauridae? indet. of ${ }^{48}$ may represent the same material as that of ${ }^{49} .{ }^{\mathrm{a}} A$ Aptian, $C$ Cenomanian, $T$ Turonian, $l$ lower, $u$ upper. ${ }^{\mathrm{b}}$ Least inclusive clade. ${ }^{\mathrm{c}}$ This study. 
the La Aguada Member (bottom); the Chejendé Member (middle) and the Timbetes Member (top) (for a detailed description see $37,39,56$ and references therein). The thickness of the La Luna Formation ranges from 100 to $300 \mathrm{~m}$, generally increasing northwards ( ${ }^{56,58}$ and references therein).

In the Lara and Trujillo states, the La Aguada Member reaches a thickness of $\sim 60 \mathrm{~m}^{39}$. The outcrops of the La Aguada Member, as exposed at the top of the "Cementos Andinos" quarry, consist of dense dark-grey limestones (less than $\sim 60-70 \mathrm{~cm}$ thick), intercalated by compact and laminated black/dark-grey shales, and abundant calcareous concretions. MCNC-1830 derives from a black shale horizon that has produced ichnofossils, molluscs, chondrichthyans $^{40}$, abundant osteichthyans ${ }^{59}$, and a marine snake ${ }^{37,60}$. The base of the La Aguada Member at the "Cementos Andinos" quarry overlays a fossiliferous dark-grey sandy limestone (personal observation, Fig. 1C) that has been identified as the top of the upper Albian Maraca Formation in the Andes of Trujillo and Lara states $^{38}$. Other authors (e.g., $\left.{ }^{61,62}\right)$ have used the term the 'La Puya member' to refer to a thin section $(<30 \mathrm{~m})$ at the top of the Peñas Altas Formation in the Andes of Lara and Trujillo (Fig. 1). Therefore, the discrepancy between the use of the Maraca Formation or the 'La Puya Member' for the thin sequence under the La Aguada Member is still unresolved ${ }^{37}$.

The precise age of the La Aguada Member and its corresponding sections across Venezuela and Colombia remains uncertain, ranging from Albian-Cenomanian ${ }^{55,61,63-65}$, lower-upper Cenomanian ${ }^{39,63-69}$ and even Cenomanian-Santonian ${ }^{70,71}$. Most relevant, perhaps, is the dating of the La Peña/San Felipe Sections by ${ }^{72}$, located in the eastern part of the Maracaibo Basin on the eastern edge of the village of Chejendé, Trujillo, which is less than $10 \mathrm{~km}$ from the "Cementos Andinos" quarry. Based on nannofossils, the La Aguada Member of Chejendé was deposited no earlier than in the latest Albian to middle Cenomanian interval ${ }^{72}$. However, only the base of the La Aguada Member was exposed, thus strongly suggesting an earliest Cenomanian age for MCNC-1830 that was recovered much higher in the section $\left({ }^{72}\right.$, p. 352 and Fig. 3A). Despite the debate on the exact age of the base of the La Luna Formation east of Lake Maracaibo (e.g., La Aguada Member), it seems that, based on the ammonite record, it becomes progressively younger westward ${ }^{63-65}$. For a detailed discussion on the age of the La Aguada Member see Supplementary Information 1.

Paleoenvironment and other vertebrates. During much of the Early Cretaceous, what is today Venezuela was covered by an epicontinental sea that rapidly transgressed during the latest Albian and Cenomanian towards the craton followed by a period of re-oxygenation ${ }^{55}$. The La Aguada Member has often been considered to cover a transitional environment between the shallow water conditions of the Maraca Formation (La Puya Member) and the pelagic low energy conditions of the La Luna Formation; however, water depths never exceeded $50 \mathrm{~m}^{38,40,55,73}$. The La Aguada Member has intervals rich in organic matter which have been suggested to be of algal origin ${ }^{40}$. Sedimentological and invertebrate (micro)fossil proxies indicate a shallow water environment (presence and abundance of globigerinid and a scarcity of globotruncanid foraminifera) with oxygenated and generally nutrient-rich surface waters and a stratified water column seem to have been present ${ }^{40,55}$. The La Luna Formation is associated with an outer shelf/upper slope paleoenvironment with a high diversity of medium to large marine vertebrates (see Supplementary Table 1) that would have served as ample food resources for opportunistic predators ${ }^{55}$. Nonetheless, the vertebrate record of the La Aguada Member remains fairly limited. A wide variety of bony fish remains have been uncovered, including scales, isolated and semi-articulated cranial and postcranial remains of Xiphactinus ${ }^{59}$, other ichthyodectiforms, enchodontids, and small indeterminate fishes ${ }^{40,64}$. A high diversity of lamniform sharks (at least 12 taxa in five clades, eight of which are anacoracids), have been described from the La Luna Formation, representing active pelagic predators and scavengers of large vertebrates and small nektobenthic predators feeding on small bony fish and invertebrates ${ }^{40}$. The new plesiosaur specimen adds to the diversity of large marine reptiles from the La Luna Formation and represents the largest predator described from the strata so far $\left({ }^{74,75}\right.$, Supplementary Table 1$)$.

Bottom water conditions were predominantly anoxic or suboxic, as indicated by the scarcity of benthic invertebrates with only rare occurrences of small bivalve moulds in the limestones (and undetermined ammonites), and some inoceramids in the calcareous concretions and a lack of reworking by bioturbation and/or high-water energy conditions (for more details see the Supplementary Information $1 ; ;^{40,55}$ ). It seems that anoxic sedimentation, possibly related to upwelling along the northwestern coast of South America, was widespread across the Venezuelan and Colombian platform and possibly even spanning a major part of northern South America and the southern Caribbean during the Cenomanian-Santonian ${ }^{55}$. Towards the top of the Chejendé Member oxygen and nutrient conditions improve and pelecypods and ammonites are more frequent in the concretion-rich portion of the section ${ }^{55}$.

\section{Material and methods}

Material. The study is based on an isolated tooth crown belonging to a brachauchenine pliosaurid of probable early Cenomanian (early Late Cretaceous) age. The specimen originates from the La Aguada Member of the La Luna Formation, Candelaria Municipality, Trujillo state, western Venezuela. It is housed at the Museo de Ciencias Naturales de Caracas in Caracas, Venezuela (MCNC) under the catalog number MCNC-1830 (Fig. 3).

The specimen (MCNC-1830) was found as part of a larger collection of fossil vertebrates at the "Cementos Andinos" quarry with the support of the authorities of the mining company. Legal authorization was issued by the Instituto del Patrimonio Cultural de Venezuela (IPC) through the collection permit No. 000327/2013, and through permission for mobilization and study No. 071/2015.

Multivariate analyses. To further assess the taxonomic affinities of MCNC-1830 and to explore its morphospace occupation among thalassophonean pliosaurids, we performed cluster and principal coordinates analyses using the dataset of ${ }^{5}$. This dataset was constructed to collectively summarize the dental morphological 

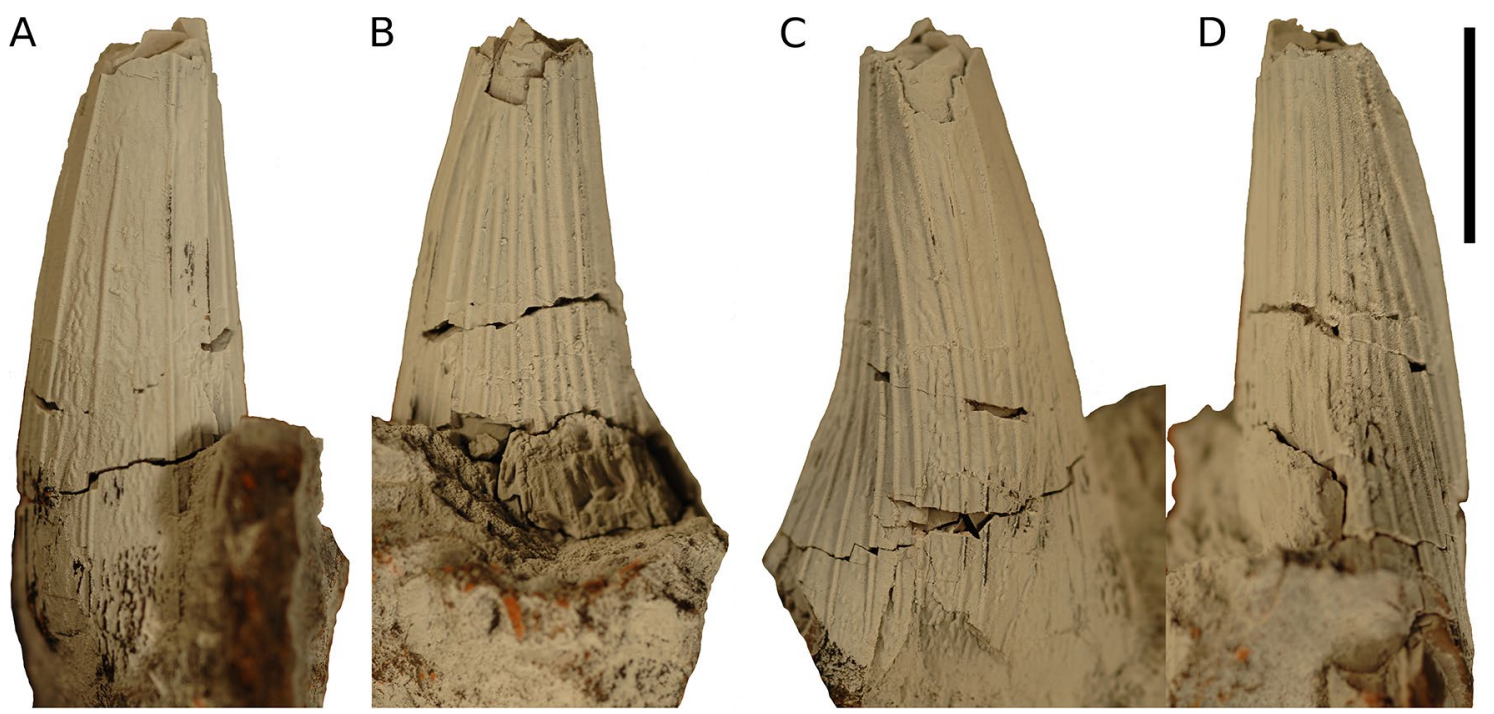

Figure 3. MCNC-1830 in (A) mesial, (B) lingual, (C) labial, and (D) distal view. Scale bar $=10 \mathrm{~mm}$. Photographs taken by Dylan Bastiaans. Figure created by Daniel Madzia using the free online application Photopea (https://www.photopea.com/).

features present in Thalassophonea. The Venezuelan taxon (MCNC-1830) and Sachicasaurus vitae ${ }^{26}$ from the upper Barremian of Sáchica, Colombia, were added to this dataset. The former was scored based on personal observations and the latter based on $^{26}$ and following discussions with Cristian David Benavides-Cabra (Universidad Nacional de Colombia, Bogotá, Colombia). We further modified the carinal score (character 3) for GFMSU h-216 $(0 \rightarrow 2)$, hereafter termed the 'Crimean pliosaurid', that was miss-scored in the original version of the dataset as lacking the carinae, while, in fact, the crown has two carinae ${ }^{5,29}$. See Supplementary Information 1 for the matrix.

We replicated the protocol of ${ }^{5}$; we applied a $50 \%$ completeness threshold to remove the influence of taxa based on insufficiently complete/preserved material, scaled the data to equal variance and a mean of zero through subtraction of the mean value for each character and then divided it by the standard deviation. A distance matrix was created using the Gower metric, that is well suited for datasets that comprise both continuous and discrete variables ${ }^{76}$. We used the cluster v2.1.0 package in the R statistical environment (RStudio Version 1.2.5033 ${ }^{77}$ ); from the resulting distance matrix a cluster dendrogram analysis using the stats base package and the Ward. D2 method was produced.

The same matrix was used to explore the dental morphospace occupation of particular thalassophonean taxa through a principal coordinates analysis, using ape v5.3 ${ }^{78}$. We again used the Gower metric and applied the Cailliez correction for negative eigenvalues. See Supplementary Information 2 for the $\mathrm{R}$ code.

The terminology of tooth crown orientation and morphology. We follow the crown orientation terminology of ${ }^{79}$ : apical, toward the crown apex; basal, toward the cervix dentis; distal, away from the tip of the snout; labial, toward the lips; lingual, toward the tongue; mesial, toward the tip of the snout. The morphological traits exposed on the outer enamel surface are described using the nomenclature as adopted by ${ }^{5,6}$ : apicobasal ridges, longitudinally running enamel ridges of variable apicobasal extent that can be developed around the entire crown circumference and are approximately semicircular or triangular in cross-section; ridglets, subtle apicobasally-expressed enamel structures that are often developed between adjacent apicobasal ridges or on an unridged enamel surface; the ridglets may be very indistinct as well as produce a distinct vermicular pattern (see ${ }^{4}$ : Fig. 7).

\section{Systematic paleontology. \\ Plesiosauria $^{80}$ \\ Pliosauridae ${ }^{81}$ \\ Thalassophonea ${ }^{35}$ \\ Brachaucheninae ${ }^{35}$ \\ Brachaucheninae indet. \\ Figure 3}

Material. MCNC-1830, an isolated tooth crown (height of the preserved part $=\sim 30 \mathrm{~mm}$ ).

Occurrence. (Most likely) lower Cenomanian, Upper Cretaceous from the La Aguada Member, La Luna Formation (see 'Geological and stratigraphic setting' for detailed information with respect to the stratigraphic context). 

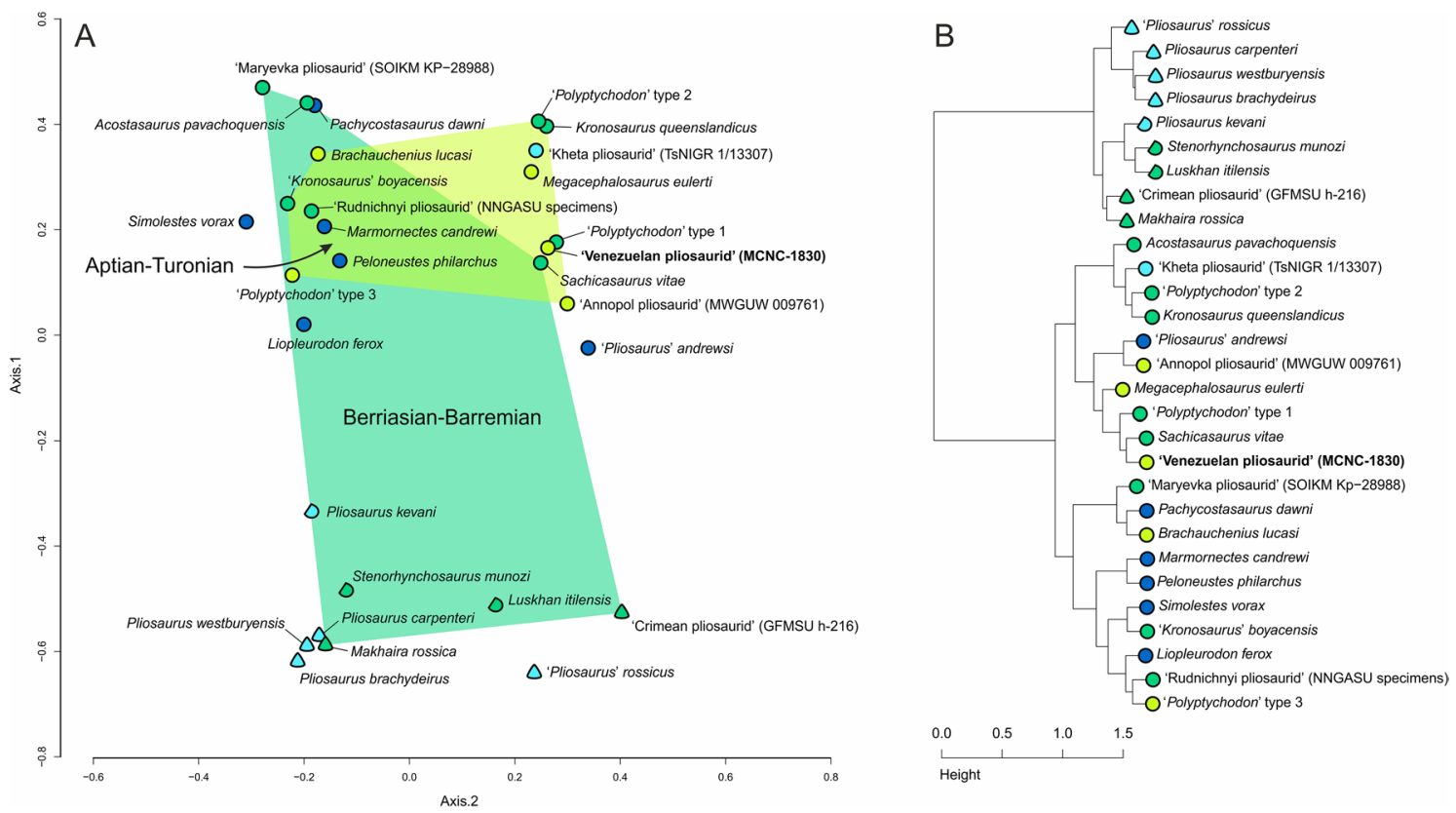

Figure 4. Results of the principal coordinates analysis (A), showing the morphospace occupation of MCNC1830 among Jurassic and Cretaceous pliosaurids, using principal coordinates 1 and 2, and results of the cluster analysis (B). Graphic representation and color scheme of the results follow ${ }^{5}$ : circles-crowns with subcircular cross-section; semicircles-crowns with subtriangular cross-section; triangles-crowns with approximately triangular cross-sections. Graphic results exported from RStudio Version 1.2.5033 ${ }^{77}$; figure created by Daniel Madzia using CorelDraw X8 (v18.1.0.661).

Description and comparisons. The apicalmost part of MCNC-1830 is broken off and the basal section is slightly compressed in labiolingual direction. Linguodistally, part of the crown is crushed near the base. The crown is conical (subcircular in cross-section), as in Acostasaurus pavachoquensis ${ }^{25}$, Brachauchenius lucasi '20,22, 'Kronosaurus' boyacensis ${ }^{15}$, Kronosaurus queenslandicus ${ }^{82}$, Megacephalosaurus eulerti ${ }^{6}$, 'Polyptychodon' hudsoni (DM, pers. obs.), Sachicasaurus vitae ${ }^{26}$, and the element-rich assemblage collectively assigned to 'Polyptychodon interruptus' reappraised by ${ }^{4}$ as probably belonging to multiple taxa, but differing from Luskhan itilensis ${ }^{28}$, Makhaira rossica ${ }^{27}$, Stenorhynchosaurus munozi $i^{24}$, and the 'Crimean pliosaurid ${ }^{29}$ that possess trihedral (M. rossica), subtrihedral (L. itilensis, S. munozi), and trihedral-to-'trapezoid' (the 'Crimean pliosaurid') cross-sectional shapes of their tooth crowns. No carinae/cutting edges are present, unlike the condition observable in L. itilensis, M. rossica, S. munozi, and the 'Crimean pliosaurid', which are characterized by the presence of one (L. itilensis, S. munozi), two (the 'Crimean pliosaurid'), and three (M. rossica) carinae. The apicobasal ridges in MCNC-1830 are approximately semicircular in cross-section and are developed around the entire circumference though they are most densely packed linguodistally. All of the ridges appear to reach the base of the crown, as is widespread among brachauchenines ${ }^{5}$. Some are very pronounced and likely reached the apex though due to the lack of the apical part, this cannot be confirmed. Some of the ridges are approaching each other on the linguodistal part of the crown, around the mid-section, but no ridges have been observed to branch, unlike in Brachauchenius lucasi, 'Polyptychodon' hudsoni, and Megacephalosaurus eulerti that typically show clear branching ridges around the mid-sections of tooth crowns. Mesiolabially, the enamel surface exposed between the apicobasal ridges shows well-pronounced ridglets, forming a vermicular pattern, similar to the state observable in Sachicasaurus vitae and some specimens from the 'Polyptychodon' assemblage, such as CAMSM B 75754.

Assessment through multivariate analyses. The results of our multivariate analyses are broadly similar to those of $^{5}$. The principal coordinates analysis (PCoA) as well as the cluster analysis recognize the presence of two general tooth crown 'morphogroups' in pliosaurids, one comprising the crowns with a conical shape (subcircular cross-section) and the other one including those with the trihedral/subtrihedral morphology (triangular/subtriangular cross-section) (Fig. 4). As $\mathrm{in}^{5}$, PCoA largely separates the two 'morphogroups' by the first principal coordinate axis (Fig. 4A). The specimen MCNC-1830 is placed on the positive sides of the first and second axis, in close proximity to Sachicasaurus vitae and the 'Polyptychodon' type 1, a tooth morphotype from the middle to upper Albian Gault Formation and the lowermost Cenomanian Cambridge Greensand Member of the West Melbury Marly Chalk Formation (late Albian in age), represented by a number of tooth crowns of differing sizes that are characterized especially by their arrangements of apicobasal ridges ( ${ }^{4}$ : Figs. $3 \mathrm{~A}, 4 \mathrm{~A}$, and 5). These crowns differ from MCNC-1830 in that their enamel surface is smoother than in MCNC-1830 and do not include wellpronounced ridglets.

A similar result, to that of the PCoA, was obtained through the cluster analysis that placed MCNC-1830 in a cluster with S. vitae and further with 'Polyptychodon' type 1 and Megacephalosaurus eulerti (Fig. 4B), within the 'conical' part of the cluster dendrogram. 


\section{Discussion}

Dental disparity of the Cretaceous pliosaurids. The results of our multivariate analyses differ in some aspects from those of ${ }^{5}$, which warrants some discussion. The addition of the late Barremian brachauchenine Sachicasaurus vitae expands the crown morphospace occupation of the pre-Aptian taxa towards the positive side of the second coordinate axis, further supporting the hypothesis that the latest brachauchenines experienced a substantial decrease in their dental disparity.

The most significant difference is the placement of GFMSU h-216 ('Crimean pliosaurid') within the 'trihedral' cluster. The analysis of ${ }^{5}$ placed the specimen among the conical-toothed taxa, in a cluster together with the Callovian (Middle Jurassic) taxon 'Pliosaurus' andrewsi and the Cenomanian (Late Cretaceous) specimen MWGUW 009761 ('Annopol pliosaurid'), none of which is particularly reminiscent of the trihedral-to- 'trapezoid' morphology of GFMSU h-216. It is worth noting that MWGUW 009761 shows a cross-section somewhat resembling a triangular shape, and may thus be characterized as being gently subtrihedral ${ }^{31}$. However, considering its overall morphology and its enamel character state distribution, we did not alter any scores for this specimen in the current version of the dataset.

The difference in the placement of GFMSU h-216 between ${ }^{5}$ and our study clearly stems for the correction of the carinal score for the specimen $(0 \rightarrow 2)$. 'Pliosaurus' andrewsi and MWGUW 009761 still cluster together among the conical-toothed pliosaurids.

Remarks on the Venezualan elasmosaurid Alzadasaurus tropicus. The most complete plesiosaur find from Venezuela is a partial postcranial skeleton (AMNH 6796) that was discovered by a Venezuelan oil company near the vicinity of Altagracia de Orituco, eastern Venezuela and established as Alzadasaurus tropicus by Colbert ${ }^{41}$. Preserved are the posteriormost cervical vertebra, four pectoral and eight dorsal vertebrae, parts of associate ribs, the left scapula, a nearly complete left and parts of the right coracoid, a left humerus as well as parts of the left radius, ulna and carpus $\left({ }^{41}\right.$, p. 4). A. tropicus was considered a 'nomen vanum' by ${ }^{44}$ (p. 54), a taxon that was adequately described but lacks sufficient diagnostic characters (nomen dubium of current use). Following Colbert's $\left({ }^{41}\right.$, p. 5) diagnosis for A. tropicus, the taxon is characterized by vertebrae with round centra and rather high, compressed, neural spines; scapula that has a broad dorsal process and a fairly broad ventral plate, not contributing to a median midline bar; an elongated coracoid that is expanded along the posterior margin, having a long posterior coracoid blade; coracoids which meet along a median symphysis anteriorly, being separated by an elongated median vacuity posteriorly; and humerus that is elongated and distally expanded.

Similar posterior cervical, pectoral or dorsal vertebrae with roundish centra and high, transversely compressed neural spines are present in various elasmosaurid taxa, including Callawayasaurus colombiensis $\left({ }^{44}\right.$, Plate 3, Fig. C), Thalassomedon haningtoni (S. Sachs pers. obs. November 2015), Futabasaurus suzukii (83, Fig. 5H), or Elasmosaurus platyurus $\left({ }^{84}\right.$, Fig. 5). A scapula with a broad dorsal process and an anteriorly broad ventral plate, lacking a pectoral bar, is a condition reminiscent of $T$. haningtoni (see ${ }^{85}$, Fig. 14). Transversely expanded anterior scapulae are present, e.g., in Libonectes morgani $\left({ }^{86}\right.$, Fig. 2 ) or Elasmosaurus platyurus $\left({ }^{44}\right.$, Fig. 14) where the scapulae form a posteromedial link to the anteromedial coracoids, called the pectoral bar. The coracoid of $A$. tropicus is expanded along the posterior margin, having a long posterior coracoid blade. The post-symphyseal coracoid, also called the coracoid blade, is usually shorter relative to the complete length of the coracoid and wider posteriorly (see e.g., ${ }^{41}$, Fig. $8{ }^{45}$, Fig. 6 for comparison). A similar elongate and narrow coracoid blade is present in the latest Cretaceous elasmosaurids Hydrotherosaurus alexandrae where the coracoid blade is, however, less elongate relative to the complete length (see ${ }^{85}$, Fig. $8{ }^{87}$, Fig. 3), and Aphrosaurus furlongi where the posterior parts of the coracoid blades are pronouncedly transversely expanded ${ }^{85}$, Fig. $23,{ }^{88}$, Fig. $\left.6 \mathrm{G}\right)$. The Turonian Libonectes morgani has clearly shorter coracoid blades $\left.{ }^{86}{ }^{6}, \mathrm{Fig} .2\right)$. The condition in the potentially coeval Cenomanian Thalassomedon haningtoni is unknown as the post-symphyseal coracoids of the holotype specimen (DMNS 1588) are not preserved. The type specimen of Alzadasaurus (FMNH 12009), described as Al. riggsi by ${ }^{85}$, was assigned to Thalassomedon by ${ }^{45}$. However, this specimen is an immature individual and most of the remains are fragmentary, heavily distorted and therefore insufficient for a confident diagnosis. The material, currently under study by SS \& DM, therefore cannot be unambiguously assigned to T. haningtoni and is best considered a nomen dubium, following ${ }^{89}$. The coracoids typically connect anteriorly along their medial symphysis, and also the posterior intercoracoid vacuity is a condition characteristic for elasmosaurid plesiosaurs (see discussion $\left.\mathrm{in}^{90}\right)$. Humeri that are elongated and distally expanded are likewise found in several elasmosaurid taxa, such as Thalassomedon haningtoni ( ${ }^{85}$, Fig. 15), Libonectes morgani $\left({ }^{91}\right.$, Fig. 7), Futabasaurus suzukii $\left({ }^{83}\right.$, Fig. 8A,B) or Aphrosaurus furlongi $\left({ }^{88}\right.$, Fig. 8$)$.

In summary, all characters considered diagnostic for Alzadasaurus tropicus, as discussed by ${ }^{41}$, are also present in the potentially coeval Cenomanian elasmosaurid Thalassomedon haningtoni, known from the midwestern USA (see discussion in ${ }^{92}$ ). Only the shape of the coracoid blade cannot be confirmed as the post-symphyseal coracoid parts are missing in the Thalassomedon holotype specimen (DMNS 1588) and the pectoral girdles are not preserved in the referred specimen (UNSM 50132) either. Several characters considered diagnostic for $A$. tropicus by ${ }^{41}$ are typical for elasmosaurids in general, such as the intercoracoid vacuity.

Even though we have not observed any characters that could be used to diagnose Alzadasaurus tropicus, confirming its status as a nomen dubium or its similarity to Thalassomedon haningtoni, which would be suggested based solely upon Colbert's ${ }^{41}$ publication, is beyond the scope of this study.

Other potential pliosaurid specimens from the Upper Cretaceous of South America. It is worth noting that two partly damaged isolated vertebral centra from the Cenomanian Romirón Formation of Peru have been recently mentioned as possibly representing a pliosaurid (referred by Meza-Velez and O'Gorman ${ }^{48}$ to as 'Pliosauroidea? indet.' and 'Pliosauridae? indet.'). However, the description of these incomplete specimens, 
representing a caudal and a sacral or proximal caudal centrum, has not been supplemented with detailed comparisons of contemporary taxa. A morphometric analysis of the specimens placed them outside the Elasmosauridae which led to the conclusion that pliosaurids are the most plausible group. However, similar proportions and a similar morphology (centra that are wider than long/high and higher than long, having amphicoelous articular faces) are also known for coeval early Late Cretaceous polycotylids (see e.g. ${ }^{93}$ ). This group was not considered in the comparisons by Meza-Velez and O'Gorman ${ }^{48}$. For that reason, and owing to the apparent homoplasy in plesiosaur vertebral characters (e.g. ${ }^{94}$ ), the taxonomic assignment is questionable. Pending more detailed assessment of the material and vertebral character distribution within Plesiosauria, the vertebrae are probably best interpreted as Plesiosauria indet.

\section{Conclusions}

With the notable exception of the pliosaurid and elasmosaurid specimens originating from the upper Aptian (Lower Cretaceous) strata of the Paja Formation in Colombia, the plesiosaur record from the mid-Cretaceous (approximately encompassing the Aptian-Turonian interval) of South America is based on fragmentary remains of indeterminate phylogenetic affinities.

Here, we report the first pliosaurid material from Venezuela. The specimen originates from the La Aguada Member of the La Luna Formation in the Andes range (Cordillera de Mérida), east of Lake Maracaibo, $10 \mathrm{~km}$ to the northeast of Monay city, Candelaria Municipality, Trujillo state, western Venezuela. It was discovered in strata most likely deposited in the early Cenomanian (earliest Late Cretaceous). Despite comprising a single tooth crown, the preservation of the specimen allows for a detailed description, comparisons to teeth of other Cretaceous pliosaurids, and an assessment through multivariate analyses of data that have become available recently.

The overall morphology of the Venezuelan specimen and the distribution of its outer enamel structural elements indicate affinities to late-diverging brachauchenines and appear to resemble especially those observable in Sachicasaurus vitae, a recently described giant pliosaurid from the upper Barremian (Lower Cretaceous) of Boyacá, Colombia.

The most complete plesiosaur material from Venezuela described to date includes a partial postcranial specimen, established as the type of Alzadasaurus tropicus. The taxon is usually considered to lack diagnostic features and is treated as a nomen dubium. Our preliminary assessment of the specimen concurs with this though we have also observed characters that are shared with the middle Cenomanian (lower Upper Cretaceous) elasmosaurid Thalassomedon haningtoni from the midwestern USA.

In turn, the Venezuelan pliosaurid represents the youngest South American representative of the clade, over $10 \mathrm{Ma}$ younger than the second youngest South American record ('Kronosaurus' boyacensis). Additionally, if the early Cenomanian age for the deposition of the fossil-bearing strata proves correct, the newly described specimen also marks the southernmost Upper Cretaceous occurrence of Pliosauridae, worldwide. Regardless, the Venezuelan pliosaurid represents a significant addition to the scarce record of the mid-Cretaceous plesiosaurs of South America and is another indicator of the potential and abundance of marine vertebrates from the Cretaceous of Venezuela.

Received: 27 March 2021; Accepted: 13 July 2021

Published online: 29 July 2021

\section{References}

1. Madzia, D. \& Cau, A. Estimating the evolutionary rates in mosasauroids and plesiosaurs: Discussion of niche occupation in Late Cretaceous seas. PeerJ 8, e8941 (2020).

2. Benson, R. B. et al. A giant pliosaurid skull from the Late Jurassic of England. PLoS ONE 8, e65989. https://doi.org/10.1371/journ al.pone.0065989 (2013).

3. Schumacher, B. A., Carpenter, K. \& Everhart, M. J. A new Cretaceous pliosaurid (Reptilia, Plesiosauria) from the Carlile Shale (middle Turonian) of Russell County, Kansas. J. Vertebrate Paleontol. 33, 613-628 (2013).

4. Madzia, D. A reappraisal of Polyptychodon (Plesiosauria) from the Cretaceous of England. PeerJ 4, e1998 (2016).

5. Zverkov, N. G., Fischer, V., Madzia, D. \& Benson, R. B. J. Increased pliosaurid dental disparity across the Jurassic-Cretaceous transition. Palaeontology 61, 825-846 (2018).

6. Madzia, D., Sachs, S. \& Lindgren, J. Morphological and phylogenetic aspects of the dentition of Megacephalosaurus eulerti, a pliosaurid from the Turonian of Kansas, USA, with remarks on the cranial anatomy of the taxon. Geol. Mag. 156, 1201-1216 (2019).

7. Tarlo, L. B. A review of the Upper Jurassic pliosaurs. Bull. Br. Museum (Nat. Hist.) Geol. Lond. 4(5), 145-189 (1960).

8. Noè, L. F. A taxonomic and functional study of the Callovian (Middle Jurassic) Pliosauroidea (Reptilia, Sauropterygia), PhD thesis, University of Derby, $616 \mathrm{pp}$ (2001).

9. Ketchum, H. F. \& Benson, R. B. J. The cranial anatomy and taxonomy of Peloneustes philarchus (Sauropterygia, Pliosauridae) from the Peterborough member (Callovian, Middle Jurassic) of the United Kingdom. Palaeontology 54(3), 639-665 (2011).

10. Knutsen, E. M. A taxonomic revision of the genus Pliosaurus (Owen, 1841a) Owen, 1841b. Norw. J. Geol. 92, 259-276 (2012).

11. Knutsen, E. M., Druckenmiller, P. S. \& Hurum, J. H. A new species of Pliosaurus (Sauropterygia: Plesiosauria) from the Middle Volgian of central Spitsbergen, Norway. Norw. J. Geol. 92, 235-258 (2012).

12. Williston, S. W. North American plesiosaurs. Field Columbian Museum, Pub. 73, Geological Series 2, 1-79 (1903).

13. Williston, S. W. The skull of Brachauchenius, with special observations on the relationships of the plesiosaurs. US Natl. Museum Proc. 32, 477-489 (1907).

14. Welles, S. P. \& Slaughter, B. H. The first record of the plesiosaurian genus Polyptychodon (Pliosauridae) from the New World. J. Paleontol. 37, 131-133 (1963).

15. Hampe, O. Ein großwüchsiger Pliosauride (Reptilia: Plesiosauria) aus der Unterkreide (oberes Aptium) von Kolumbien. Courier Forschungs-Institut Senckenberg 145, 1-32 (1992).

16. Carpenter, K. A review of short-necked plesiosaurs from the Cretaceous of the Western Interior, North America. Neues Jb. Geol. Paläontol. Abh. 201, 259-287 (1996).

17. VonLoh, J. P. \& Bell, G. L. Jr. Fossil Reptiles from the Late Cretaceous Greenhorn Formation (Late Cenomanian-Middle Turonian) of the Black Hills Region, South Dakota. Dakoterra 5, 28-38 (1998). 
18. Kear, B. P. Cretaceous marine reptiles of Australia: A review of taxonomy and distribution. Cretac. Res. 24, 277-303 (2003).

19. Hampe, O. Considerations on a Brachauchenius skeleton (Pliosauroidea) from the lower Paja Formation (late Barremian) of Villa de Leyva area (Colombia). Fossil Record 8, 37-51 (2005).

20. Liggett, G. A., Shimada, K., Bennett, S. C. \& Schumacher, B. A. Cenomanian (Late Cretaceous) reptiles from northwestern Russell County, Kansas. PaleoBios 25, 9-17 (2005).

21. Schumacher, B. A. \& Everhart, M. J. A stratigraphic and taxonomic review of plesiosaurs from the old "Fort Benton Group" of central Kansas: A new assessment of old records. Paludicola 5, 33-54 (2005).

22. Albright, B. L., Gillette, D. D. \& Titus, A. L. Plesiosaurs from the Upper Cretaceous (Cenomanian-Turonian) tropic shale of southern Utah. Part 1: New records of the pliosaur Brachauchenius lucasi. J. Vertebrate Paleontol. 27, 41-58 (2007).

23. Ketchum, H. F. \& Benson, R. B. J. Global interrelationships of Plesiosauria (Reptilia, Sauropterygia) and the pivotal role of taxon sampling in determining the outcome of phylogenetic analyses. Biol. Rev. 85, 361-392 (2010).

24. Páramo-Fonseca, M. E., Gómez-Pérez, M., Noè, L. F. \& Etayo-Serna, F. Stenorhynchosaurus munozi, gen. et sp. nov. a new pliosaurid from the Upper Barremian (Lower Cretaceous) of Villa de Leiva, Colombia, South America. Revista de la Academia Colombiana de Ciencias Exactas Físicas y Naturales 40, 84-103 (2016).

25. Gómez-Pérez, M. \& Noè, L. F. Cranial anatomy of a new pliosaurid Acostasaurus pavachoquensis from the Lower Cretaceous of Colombia, South America. Palaeontogr. Abt. A 310, 5-42 (2017).

26. Páramo-Fonseca, M. E., Benavides-Cabra, C. D. \& Gutiérrez, I. E. A new large pliosaurid from the Barremian (Lower Cretaceous) of Sáchica, Boyacá, Colombia. Earth Sci. Res. J. 22, 223-238 (2018).

27. Fischer, V. et al. Peculiar macrophagous adaptations in a new Cretaceous pliosaurid. R. Soc. Open Sci. 2, 150552 (2015).

28. Fischer, V. et al. Plasticity and convergence in the evolution of short-necked plesiosaurs. Curr. Biol. 27, 1667-1676.e3 (2017).

29. Zverkov, N. G. On a typically Late Jurassic pliosaur from the Lower Cretaceous of Crimea. The International Scientific Conference on the Jurassic/Cretaceous boundary, Samara, Russia, 89-94 (2015).

30. Angst, D. \& Bardet, N. A new record of the pliosaur Brachauchenius lucasi [Williston, 1903] (Reptilia: Sauropterygia) of Turonian (Late Cretaceous) age, Morocco. Geol. Mag. 153, 449-459 (2016).

31. Madzia, D. \& Machalski, M. Isolated pliosaurid teeth from the Albian-Cenomanian (Cretaceous) of Annopol, Poland. Acta Geol. Pol. 67, 393-403 (2017).

32. Lukeneder, A. \& Zverkov, N. G. First evidence of a conical-toothed pliosaurid (Reptilia, Sauropterygia) in the Hauterivian of the Northern Calcareous Alps, Austria. Cretaceous Res. 106, 104248 (2020).

33. Zverkov, N. G. \& Pervushov, E. M. A gigantic pliosaurid from the Cenomanian (Upper Cretaceous) of the Volga Region, Russia. Cretaceous Res. 110, 104419 (2020).

34. Kear, B. P., Ekrt, B., Prokop, J. \& Georgalis, G. L. Turonian marine amniotes from the Bohemian Cretaceous Basin, Czech Republic. Geol. Mag. 151, 183-198 (2014).

35. Benson, R. B. J. \& Druckenmiller, P. S. Faunal turnover of marine tetrapods during the Jurassic-Cretaceous transition. Biol. Rev. 89, 1-23 (2014).

36. Páramo-Fonseca, M. E., Benavides-Cabra, C. D. \& Gutiérrez, I. E. A new specimen of Stenorhynchosaurus munozi (Páramo-Fonseca et al., 2016) (Plesiosauria, Pliosauridae), from the Barremian of Colombia: new morphological features and ontogenetic implications. J. Vertebrate Paleontol. 39, e1663426 (2019).

37. Albino, A. M., Carrillo-Briceño, J. D. \& Neenan, J. M. An enigmatic snake from the Cenomanian of Northern South America. PeerJ 4, e2027. https://doi.org/10.7717/peerj.2027 (2016).

38. de Juana, C. G., de Arocena, J. I. \& Picard, X. Geologia de Venezuela y de sus Cuencas Petroliferas Vol. 103, 1 (Foninves, 1980).

39. Renz, O. Estratigrafía del Cretáceo en Venezuela occidental. Boletín de Geología 5(10), 3-48 (1959).

40. Guinot, G. \& Carrillo-Briceño, J. D. Lamniform sharks from the Cenomanian (Upper Cretaceous) of Venezuela. Cretac. Res. 82, $1-20$ (2018).

41. Colbert, E. A new Cretaceous plesiosaur from Venezuela. Am. Mus. Novit. 1420, 1-22 (1949).

42. Bengston, P. \& Kakabadze, M. V. Ammonites and the mid-Cretaceous saga. Cretac. Res. 88, 90-99 (2018).

43. Páramo-Fonseca, M. E., O’Gorman, J. P., Gasparini, Z., Padilla, S. \& Parra-Ruge, M. L. A new late Aptian elasmosaurid from the Paja Formation, Villa de Leiva, Colombia. Cretaceous Res. 99, 30-40 (2019).

44. Welles, S. P. A new species of elasmosaur from the Aptian of Colombia, and a review of the Cretaceous plesiosaurs. Univ. California Publ. Geol. Sci. 44, 1-96 (1962).

45. Carpenter, K. Revision of North American elasmosaurs from the Cretaceous of the Western Interior. Paludicola 2, 148-173 (1999).

46. Jaimes, J. J. \& Parra, E. N. Callawayasaurus colombiensis (Welles) Carpenter 1999 el plesiosaurio de Villa de Leyva (Boyacá, Colombia). ¿Un nuevo espécimen?. Boletín de Geología 23(38), 9-19 (2001).

47. Goñi, R. \& Gasparini, Z. B. Nuevos restos de "Alzadasaurus colombiensis" (Reptilia, Plesiosauria) del Cretácico temprano de Colombia. Geologia Norandina 7, S.49-54 (1983).

48. Meza-Velez, I. \& O’Gorman, J. E. registro fósil de plesiosaurios (Diapsida, Sauropterygia) en el Perú. Rev. Peru. Biol. 28(2), 1-8 (2021).

49. Jaillard, E., Cordova, A., Mazin, J.-M. \& Mourier, T. La transgression du Cénomanien supérieur-Turonien inférieur dans le région de Jaén (Nord du Pérou): donnés sédimentologique et stratigraphiques: Découverte du premier saurien marin du Pérou, Série II. C. R. Acad. Sc. Paris 301(20), 1429-1432 (1985).

50. Carvalho, I., Velas Bôas, I. \& Bergqvist, L. Plesiossauros da regiao equatorial Brasileira Bacia de Sao Luís (Cretáceo Superior) Brazil. Acta Geologica Leopoldensia 23(51), S33-S41 (2000).

51. Velas Bôas, I. \& Carvalho, I. Répteis Marinhos (Mosasauria e Plesiosauria) do Cretáceo Superior da Bacia de São Luís (Maranhão, Brasil). O Cretáceo na Bacia de São Luís-Grajaú, 223-233 (2001).

52. O'Gorman, J. P. \& Varela, A. N. The oldest lower Upper Cretaceous plesiosaurs (Reptilia, Sauropterygia) from southern Patagonia, Argentina. Ameghiniana 47, 447-459 (2010).

53. Ameghino, F. Sobre la presencia de vertebrados de aspecto mesozoico en la formación Santacruceña de la Patagonia austral. Revista del Jardín Zoológico de Buenos Aires 1, 76-84 (1893).

54. Zumberge, J. E. Source rocks of the La Luna Formation (Upper Cretaceous) in the Middle Magdalena Valley, Colombia. Petroleum geochemistry and source rock potential of carbonate rocks. AAPG Stud. Geol. 18, 127133 (1984).

55. Tribovillard, N. P. et al. Cretaceous black shales of Venezuelan Andes: Preliminary results on stratigraphy and paleoenvironmental interpretations. Palaeogeogr. Palaeoclimatol. Palaeoecol. 81, 313-321 (1991).

56. Bralower, T. J. \& Lorente, M. A. Paleogeography and stratigraphy of the La Luna Formation and related Cretaceous anoxic depositional systems. Palaios 18(4-5), 301-304 (2003).

57. Zapata, E. et al. Biostratigraphic, sedimentologic, and chemostratigraphic study of the La Luna Formation (Late Turonian-Campanian) in the San Miguel and Las Hernández sections, western Venezuela. Palaios 18, 367-377. https://doi.org/10.1669/08831351(2003)018\%3c0367:BSACSO\%3e2.0.CO;2 (2003).

58. MINISTERIO DE ENERGIA Y MINAS. Lexico Estratigraifico de Venezuela, 3'd ed. Boletin de Geologia 12, 1-828 (1997).

59. Carrillo Briceño, J. D., Alvarado-Ortega, J. \& Patiño Torres, C. Primer registro de Xiphactinus Leidy, 1870 (Teleostei, Ichthyodectiformes) en el Cretácico Superior de América del Sur (Formación La Luna, Venezuela). Revista Brasileira de Paleontologia. 15(3), 327-335 (2012). 
60. Albino, A. M., Rothschild, B., Carrillo-Briceño, J. D. \& Neenan, J. M. Spondyloarthropathy in vertebrae of the aquatic Cretaceous snake Lunaophis aquaticus, and its first recognition in modern snakes. Sci. Nat. 105(9), 51 (2018).

61. Renz, O. Die Ammonoidea im Stratotyp des Vraconien bei Sainte Croix (Kanton Waadt). Schweizerische palaontologische Abhandlungen 87, 1-97 (1968).

62. Erlich, R. N., Macsotay, O., Nederbragt, A. J. \& Lorente, M. A. Palaeoceanography, palaeoecology, and depositional environments of Upper Cretaceous rocks of western Venezuela. Palaeogeogr. Palaeoclimatol. Palaeoecol. 153, 203-238 (1999).

63. Renz, O. The Cretaceous Ammonites of Venezuela (Birkhäuser Verlag, 1982).

64. Moody, J. M. \& Maisey, J. G. New Cretaceous marine vertebrate assemblages from North-Western Venezuela and their significance. J. Vertebr. Paleontol. 14(1), 1-8 (1994).

65. Macsotay, O., Erlich, R. N. \& Peraza, T. Sedimentary structures of the La Luna, Navay and Querecual Formations, Upper Cretaceous of Venezuela. Palaios 18(4-5), 334-348 (2003).

66. Davis, C., Pratt, L. \& Sliter, W. Factors influencing organic carbon and trace metal accumulation in the Upper Cretaceous La Luna Formation of the western Maracaibo Basin, Venezuela. In Evolution of the Cretaceous Ocean-Climate System Vol. 332 (eds Barrera, E. \& Johnson, C. C.) 203-231 (Geological Society of America Special Paper Geological Society of America, 1999).

67. Martinez, J. I. \& Hernandez, R. Evolution and drowning of the Late Cretaceous Venezuelan carbonate platform. J. S. Am. Earth Sci. 5(2), 197-210 (1992).

68. Ford, A. B., \& Houbolt, J. J. H. C. The microfacies of the Cretaceous of western Venezuela: International Sedimentary Petrographical Series 6. EJ Brill, Publisher, Leiden, Germany, 1-109 (1963).

69. Caron, M. \& Spezzaferri, S. Scanning electron microscope documentation of the lost holotypes of Mornod, 1949: Thalmanninella reicheli and Rotalipora montsalvensis. J. Foraminiferal Res. 36(4), 374-378 (2006).

70. Veigal, R. \& Dzelalija, F. A Regional Overview of the La Luna Formation and the Villeta Groups as Shale Gas/Shale Oil in the Catatumbo Magdalena Valley and Eastern Cordillera Regions, Colombia, Article \#10565 21 (American Association of Petroleum Geologists, Search and Discovery, 2014).

71. Spickert, A. Petroleum System Analysis: Middle Magdalena Valley Basin, Colombia, South America. MSC Report 1-48 (University of Washington, 2014).

72. De Romero, L. M. et al. An integrated calcareous microfossil biostratigraphic and carbon-isotope stratigraphic framework for the La Luna Formation, western Venezuela. Palaios 18(4-5), 349-366 (2003).

73. Mendez, C. E. La Formacion La Luna. Caracteristica de una cuenca anoxica en una plataforma de aguas someras. Proceedings of the 7th Congreso Geologico Venezolano, 852-866 (1981).

74. Weiler, W. Fischreste aus der Umgebung von San Cristobal, SW. Venezuela. Zentralblatt für Mineralogie Geologie und Paläontologie (B). 1949, 240-255 (1940).

75. Sánchez-Villagra, M. R., Brinkmann, W. \& Lozsán, R. The Paleozoic and Mesozoic vertebrate record of Venezuela: An overview, summary of previous discoveries and report of a mosasaur from the La Luna Formation (Cretaceous). Paläontol. Z. 82(2), 113-124 (2008).

76. Gower, J. C. A general coefficient of similarity and some of its properties. Biometrics 27(4), 857-871 (1971).

77. RStudio Team. RStudio: Integrated Development for R. RStudio, Inc., Boston, MA. http://www.rstudio.com/ (2019).

78. Paradis, E., Claude, J. \& Strimmer, K. APE: analyses of phylogenetics and evolution in R language. Bioinformatics 20, 289-290 (2004).

79. Smith, J. B. \& Dodson, P. A proposal for a standard terminology of anatomical notation and orientation in fossil vertebrate dentitions. J. Vertebr. Paleontol. 23, 1-12 (2003).

80. de Blainville, H. D. Description de quelques espècesde reptiles de la Californie, précédé de l’analyse d'unsystème général d'Erpétologie et d'Amphibiologie. Nouvelles Annales du Museum National d'Histoire Naturelle Paris 4, 233-296 (1835).

81. Seeley, H. G. Note on some of the generic modifications of the plesiosaurian pectoral arch. Q. J. Geol. Soc. Lond. 30, 436-449 (1874).

82. McHenry, C. R. Devourer of gods: The palaeoecology of the Cretaceous pliosaur Kronosaurus queenslandicus. Doctoral dissertation, University of Newcastle (2009).

83. Sato, T., Hasegawa, Y. \& Manabe, M. A new elasmosaurid plesiosaur from the Upper Cretaceous of Fukushima, Japan. Palaeontology 49, 467-484 (2006).

84. Sachs, S. Redescription of Elasmosaurus platyurus Cope 1868 (Plesiosauria: Elasmosauridae) from the Upper Cretaceous (lower Campanian) of Kansas, USA. Paludicola 5, 92-106 (2005).

85. Welles, S. P. Elasmosaurid plesiosaurs with a description of new material from California and Colorado. Univ. California Publ. Geol. Sci. 13, 125-215 (1943).

86. Welles, S. P. A new elasmosaur from the Eagle Ford Shale of Texas. Part I. Systematic description. Fondren Sci. Series 1, 1-28 (1949).

87. Sachs, S. Remarks on the pectoral girdle of Hydrotherosaurus alexandrae (Plesiosauria: Elasmosauridae). PalArch Vertebr. Palaeontol. 4(1), 1-6 (2005).

88. O'Gorman, J. P. Elasmosaurid phylogeny and paleobiogeography, with a reappraisal of Aphrosaurus furlongi from the Maastrichtian of the Moreno Formation. J. Vertebr. Paleontol. 39(5), el692025 (2020).

89. Sachs, S., Kear, B.P. \& Lindgren, J. Re-description of Thalassomedon haningtoni-An elasmosaurid from the Cenomanian of North America. 5th Triennial Mosasaur Meeting-A Global Perspective on Mesozoic Marine Amniotes. Abstracts and Program (Sachs, S., Kear, B.P. \& Lindgren, eds.), 38-40 (2016).

90. Sachs, S. \& Kear, B. P. Postcranium of the paradigm elasmosaurid plesiosaurian Libonectes morgani (Welles, 1949). Geol. Mag. 152, 694-710 (2015).

91. Sachs, S. \& Kear, B. P. Redescription of the elasmosaurid plesiosaurian Libonectes atlasense from the Upper Cretaceous of Morocco. Cretac. Res. 74, 205-222 (2017).

92. Sachs, S., Lindgren, J., Madzia, D. \& Kear, B. P. Cranial osteology of the mid-Cretaceous elasmosaurid Thalassomedon haningtoni from the Western Interior Seaway of North America. Cretaceous Res. 123,104769 (2021).

93. McKean, R. S. A new species of polycotylid plesiosaur (Reptilia: Sauropterygia) from the Lower Turonian of Utah: Extending the stratigraphic range of Dolichorhynchops. Cretac. Res. 34, 184-199 (2012).

94. Sachs, S., Madzia, D., Püttmann, T. \& Kear, B. P. Enigmatic plesiosaur vertebral remains from the middle Turonian of Germany. Cretaceous Res. 110, 104406 (2020).

\section{Acknowledgements}

We would like to express our gratitude to Engelberth Montilla, Crisanto Silva, Norelis Valera, and Cementos Andinos CA., for assistance during the fieldwork. We would also like to thank the authorities at the Instituto del Patrimonio Cultural de Venezuela for the permissions to collect and study the specimen. Hyram Moreno and Edwin Chávez-Aponte (Museo de Ciencias Naturales de Caracas) are further thanked for their valuable collaboration. Finally, we would like to thank Cristian David Benavides-Cabra (Universidad Nacional de Colombia, Bogotá, Colombia) for information on the dental anatomy of Sachicasaurus vitae, and María Eurídice PáramoFonseca (Universidad Nacional de Colombia, Bogotá, Colombia) and two anonymous reviewers for their constructive and helpful comments that have improved this manuscript. 


\section{Author contributions}

D.B. and D.M. designed the project. D.B. prepared Fig. 2, Supplementary Fig. 1, and Supplementary Table 1. D.M. compiled data for multivariate analyses, carried out the analyses, and prepared Figs. 3 and 4. J.D.C.-B. prepared Fig. 1. S.S. prepared Table 1. All authors participated to the writing process and gave final approval for publication.

\section{Funding}

DB was partially funded through the Swiss National Science Foundation (Grant no. 31003 A_179401 to T. Scheyer).

\section{Competing interests}

The authors declare no competing interests.

\section{Additional information}

Supplementary Information The online version contains supplementary material available at https://doi.org/ 10.1038/s41598-021-94515-8.

Correspondence and requests for materials should be addressed to D.M.

Reprints and permissions information is available at www.nature.com/reprints.

Publisher's note Springer Nature remains neutral with regard to jurisdictional claims in published maps and institutional affiliations.

(c) (i) Open Access This article is licensed under a Creative Commons Attribution 4.0 International License, which permits use, sharing, adaptation, distribution and reproduction in any medium or format, as long as you give appropriate credit to the original author(s) and the source, provide a link to the Creative Commons licence, and indicate if changes were made. The images or other third party material in this article are included in the article's Creative Commons licence, unless indicated otherwise in a credit line to the material. If material is not included in the article's Creative Commons licence and your intended use is not permitted by statutory regulation or exceeds the permitted use, you will need to obtain permission directly from the copyright holder. To view a copy of this licence, visit http://creativecommons.org/licenses/by/4.0/.

(C) The Author(s) 2021 